\title{
Effect of Irrigation with Diluted Winery Wastewater on the Performance of Two Grass Cover Crops in Vineyards
}

\author{
J.C.Fourie $^{1 *}$, H. Theron ${ }^{2}$, C.H. Ochse \\ (1) ARC Infruitec-Nietvoorbij, Private Bag X5026, Stellenbosch, 7599 South Africa \\ (2) Cape Peninsula University of Technology, Private Bag X8, Wellington, 7654 South Africa
}

Submitted for publication: October 2014

Accepted for publication: December 2014

Key words: Chemical oxygen demand, cellar effluent, catch crops, interception crops, cover crops, grapevine, soil cultivation

\begin{abstract}
Pennisetum glaucum L. cv. Babala (pearl millet) established as a summer catch crop followed by Avena sativa L. cv Palinup (oats) established as a winter catch crop were irrigated with winery wastewater diluted to eight chemical oxygen demand (COD) levels ranging between $100 \mathrm{mg} / \mathrm{L}$ and $3000 \mathrm{mg} / \mathrm{L}$. The diluted wastewater treatments were compared to irrigation with river water. The dry matter production (DMP) of oats, if not preceded by pearl millet, tended to improve when irrigated with winery wastewater. Growth of pearl millet peaked during the period when $91 \%$ of the diluted winery wastewater was applied. Winery wastewater improved the DMP of pearl millet. No trends were observed in the nutrient levels of the above-ground growth of the two interception crops. However, Na levels increased over time. Using both species, too high levels of macro-nutrients were intercepted, but insignificant amounts of Na were removed. Irrigation with winery wastewater with COD levels between $1500 \mathrm{mg} / \mathrm{L}$ and $2500 \mathrm{mg} / \mathrm{L} \mathrm{may}$ be sustainable if only pearl millet is employed as an interception crop. Fertiliser needed to maintain the nutrient balance in the soil resulted in an additional cost of approximately $R 2$ 800/ha/yr. However, the fodder may provide an income in excess of $\mathrm{R} 15 \mathrm{000} / \mathrm{ha} / \mathrm{yr}$.
\end{abstract}

\section{INTRODUCTION}

Untreated winery wastewater is not permitted to be disposed of in natural water resources (Van Schoor, 2001). The South African wine grape industry produced approximately 1095 million litres of wine during 2012 (SAWIS, 2013). Every litre of wine produced results in two to 14 litres of effluent (Lagoudi et al., 2004). Therefore, cellars in the local industry are estimated to generate between 2190 million and 15330 million litres of effluent per annum. Currently, wine cellars in South Africa are processing cellar effluent by means of aerated ponds, aerobic facultative lagoons and high-rate system bioreactors (Lagoudi et al., 2004). More recently, constructed wetlands were also considered (Mulidzi, 2005), the latter being the most biologically active natural ecosystems on earth (Shepherd \& Grismer, 1997). Although the cost of constructed wetlands is low in comparison to other treatment systems, the construction of a $56.7 \mathrm{~m}^{3}$ pore volume wetland still amounted to approximately R51 000, excluding VAT and labour (Mulidzi, 2008).

According to Lagoudi et al. (2004), land surface applications such as vineyard and field irrigation are also disposal methods to be considered. Irrigation with winery wastewater is a practice increasingly applied by grape growers (Kumar \& Christen, 2009, in Laurenson et al., 2012).
Wastewater from agricultural sources can function as a source of organic matter and nutrients (Cameron et al., 1996) that may enhance crop growth and yield (Al-Jaloud et al., 1995; Vasquez-Montiel et al., 1996). However, it may also increase soil salinity, result in an undesirable soil $\mathrm{pH}$, cause excessive leaching of nutrients and heavy metals and adversely affect the physical properties of the soil (Shainberg \& Oster, 1978; Cameron et al., 1996; Wang et al., 2007).

The characteristics of winery wastewater fluctuate considerably and are determined by the size of the winery, treatment processes, as well as the pre-vintage, vintage and post-vintage activities in the cellar. The potassium $(\mathrm{K})$ content of grape juice (2 000 to $3000 \mathrm{mg} / \mathrm{L}$ ) and cleaning products (potassium hydroxide) used in the cellar may cause the $\mathrm{K}$ concentration in winery wastewater to be as high as $1000 \mathrm{mg} / \mathrm{L}$ during the vintage season (Arienzo et al., 2009a). This is classified by Mulidzi et al. (2009) as being high (above 200 mg/L). However, Arienzo et al. (2009b) suggest that sodium $(\mathrm{Na})$-based cleaning agents should be replaced by K-based cleaning agents, due to the greater potential for $\mathrm{K}$ uptake and removal by crops grown on land application sites. Most of the $\mathrm{K}$ in wastewater is in mineral form and therefore immediately available for plant uptake (Mengel et al., 2001).

*Corresponding author: E-mail:fouriej@arc.agric.za

Acknowledgements: The authors thank the Water Research Commission (WRC) for funding the research (Project K5/1881). The research was co-funded by Winetech and the Agricultural Research Council. The authors also thank Messrs Willie and Daniël Botha, for managing the vineyard and for general assistance, as well as the staff of the Soil and Water Science Programme at the ARC Infruitec-Nietvoorbij, for technical support 
When using winery wastewater for irrigation, an application strategy that will minimise leaching from the crop root zone needs to be developed (Arienzo et al., 2009a). This can be done by synchronising wastewater applications to maximise nutrient uptake by the crop. However, irrigation with winery wastewater caused a decline in the nutrient status of grapevines (Neilsen et al., 1989; McCarthy, 2010, in Laurenson et al., 2012). A progressive increase in soil salinity resulted in nutrient deficiencies (McCarthy, 1981; Paranychianakis et al., 2006) and may cause osmotic stress, lower photosynthetic activity, lead to poor nutrient utilisation and a reduction in shoot and root growth, as well as result in a decline in bunch number and berry weight (McCarthy, 1981; Prior et al., 1992; Leske et al., 1997; Stevens \& Walker, 2002; Paranychianakis et al., 2006).

Grasses have a high $\mathrm{K}$ removal potential (Arienzo et al., 2009a). Lolium species (ryegrass) have the potential to remove between 484 and $708 \mathrm{~kg} / \mathrm{ha} \mathrm{K}$ from the soil (Gamroth \& Moore, 1995, in Arienzo et al., 2009a). However, the species have developed resistance to two non-selective broad-spectrum herbicides, namely paraquat and glyphosate (Busi \& Powles, 2011). It therefore should not be considered as a catch crop for the interception of excess nutrients applied by means of irrigation with winery wastewater. According to Pederson et al. (2002), Avena sativa L. (oats) has the potential to be used as a catch crop, with hay production and sale off-farm as a viable method for removing excess nutrients. Pennisetum glaucum L. (pearl millet) is also widely used as fodder in developing countries (Blümmel et al., 2003; Al Suhaibani, 2011; Khan et al., 2012). It also can be an important summer cereal crop that does not require a lot of irrigation due to its short growing season (Khan et al., 2012). Al-Jaloud et al. (1995) indicated that the irrigation of sorghum plants with wastewater did not increase the mineral concentrations in the plants, while Albassam (2001) observed that the negative effect of a high concentrations of $\mathrm{Na}$ in irrigation water on the growth of pearl millet could be restored partially by the application of nitrogen $(\mathrm{N})$. In general, pearl millet is considered to be fairly saline tolerant (Krishnamurthy et al., 2007), which can be associated with a reduced $\mathrm{N}$ content in the shoots and an increase in the $\mathrm{K}$ and $\mathrm{Na}$ content.

The aim of this study was (1) to determine whether irrigation with winery wastewater at different COD levels affected the performance and nutrient content of oats and pearl millet, and (2) to determine the ability of these two species to intercept sufficient amounts of $\mathrm{Na}$ and $\mathrm{K}$ as a catch crop on a sandy soil.

\section{MATERIALS AND METHODS Experiment vineyard and layout}

The field trial was executed in an eight-year-old microsprinkler-irrigated Cabernet Sauvignon/99 Richter vineyard near Rawsonville, South Africa ( $33^{\circ} 41^{\prime}$ latitude) established on a sandy soil. Details of the irrigation infrastructure, dilution procedures, trellis system, climate, soil preparation and the type of soil have been reported by Myburgh et al. (2014).

The summer catch crop Pennisetum glaucum L. hybrid Babala (pearl millet), followed by the winter catch crop Avena sativa L. cv. Pallinup (oats), was irrigated with winery wastewater diluted to eight chemical oxygen demand (COD) levels ranging between $100 \mathrm{mg} / \mathrm{L}$ and $3000 \mathrm{mg} / \mathrm{L}$ (T2 to T9) (Table 1), as described by Myburgh et al. (2014). These treatments were compared with a treatment in which pearl millet and oats were irrigated with river water throughout the season (T1). The diluted winery wastewater was applied from mid-February to either mid-April or the beginning of May (Howell et al., 2014). The irrigation volumes, water quality and amount of mineral elements applied via the irrigation water during the 2009/2010, 2010/2011, 2011/2012 and 2012/2013 seasons are discussed in detail by Howell et al. (2014).

All treatments were replicated three times in a randomised block design. Each experiment plot consisted of two rows of six grapevines each, with two buffer grapevines between plots in the same vine rows, three grapevine inter-rows and two buffer vine rows between plots in different rows.

\section{TABLE 1}

Dry matter production (DMP) of the winter growing cover crop, Avena sativa L. cv. Pallinup (oats), established on a sandy soil near Rawsonville and irrigated with cellar effluent diluted to different chemical oxygen demand (COD) levels, as measured during 2010, 2011, 2012 and 2013.

\begin{tabular}{|c|c|c|c|c|c|c|}
\hline \multirow{3}{*}{$\begin{array}{l}\text { Treatment No. \& } \\
\text { target COD }(\mathrm{mg} / \mathrm{L})\end{array}$} & \multicolumn{6}{|c|}{$\operatorname{DMP}(\mathrm{t} / \mathrm{ha})$} \\
\hline & \multicolumn{3}{|c|}{2010} & \multirow{2}{*}{$\frac{2011}{22 \text { Sept }}$} & \multirow{2}{*}{$\begin{array}{c}2012 \\
4 \text { Sept }\end{array}$} & \multirow{2}{*}{$\begin{array}{r}2013 \\
11 \mathrm{Sep}\end{array}$} \\
\hline & 29 July & 29 Sept & Total & & & \\
\hline T1 - Control ${ }^{(1)}$ & $4.08 \mathrm{a}^{(2)}$ & $1.35 \mathrm{a}$ & $5.43 \mathrm{a}$ & $2.75 \mathrm{~b}$ & $8.27 \mathrm{a}$ & $8.59 \mathrm{a}$ \\
\hline $\mathrm{T} 2-100$ & $3.30 \mathrm{a}$ & $2.45 \mathrm{a}$ & $5.75 \mathrm{a}$ & $4.01 \mathrm{ab}$ & $4.76 \mathrm{a}$ & $7.27 \mathrm{a}$ \\
\hline $\mathrm{T} 3-250$ & $3.24 \mathrm{a}$ & $1.98 \mathrm{a}$ & $5.22 \mathrm{a}$ & $4.68 \mathrm{ab}$ & $7.08 \mathrm{a}$ & $7.36 \mathrm{a}$ \\
\hline $\mathrm{T} 4-500$ & $4.04 \mathrm{a}$ & $1.71 \mathrm{a}$ & $5.75 \mathrm{a}$ & $6.26 \mathrm{a}$ & $7.72 \mathrm{a}$ & $7.29 \mathrm{a}$ \\
\hline T5 - 1000 & $3.44 \mathrm{a}$ & $1.97 \mathrm{a}$ & $5.41 \mathrm{a}$ & $4.42 \mathrm{ab}$ & $6.78 \mathrm{a}$ & $7.58 \mathrm{a}$ \\
\hline T6 - 1500 & $3.62 \mathrm{a}$ & $1.92 \mathrm{a}$ & $5.54 \mathrm{a}$ & $5.64 \mathrm{a}$ & $7.21 \mathrm{a}$ & $8.30 \mathrm{a}$ \\
\hline T7 - 2000 & $2.56 \mathrm{a}$ & $2.62 \mathrm{a}$ & $5.18 \mathrm{a}$ & $5.36 \mathrm{a}$ & $7.26 \mathrm{a}$ & $9.12 \mathrm{a}$ \\
\hline $\mathrm{T} 8-2500$ & $2.70 \mathrm{a}$ & $2.03 \mathrm{a}$ & $4.73 \mathrm{a}$ & $4.46 \mathrm{ab}$ & $6.05 \mathrm{a}$ & $6.02 \mathrm{a}$ \\
\hline T9 - 3000 & $3.35 \mathrm{a}$ & $2.02 \mathrm{a}$ & $5.37 \mathrm{a}$ & $4.45 \mathrm{ab}$ & $4.84 \mathrm{a}$ & $5.99 \mathrm{a}$ \\
\hline
\end{tabular}

\footnotetext{
${ }^{(1)}$ Water extracted from the Holsloot River. ${ }^{(2)}$ Values followed by the same letter within a column do not differ significantly $(\mathrm{p} \leq 0.05)$
} 


\section{Seeding density, seeding date and seedbed preparation}

Oats were sown as a winter interception crop at a seeding density of $100 \mathrm{~kg} / \mathrm{ha}$ (Fourie et al., 2001) on 2010-04-14 and 2011-04-07, as suggested by Fourie et al. (2006b), to maximise production. Seedbed preparation was done with a disc harrow approximately six weeks before the seeding date to allow for the breakdown of any mulch material on the soil surface that may have a negative effect on seed germination and the growth of the young seedlings. During 2012 and 2013 the oats had to be sown during the last week of April due to the second (final) harvest of pearl millet occurring on 2012-04-23 and 2013-04-22. This did not allow for any seedbed preparation. However, the pearl millet residues were incorporated into the soil just before the seeds were sown. After sowing by hand, the seeds were covered with soil using a disc harrow. Pearl millet was sown on 2010-11-23 at a seeding density of $30 \mathrm{~kg} / \mathrm{ha}$ as suggested by the supplier (Agricol, Brackenfell) to ensure effective germination and sufficient growth during the 2011 grape harvest period. An irrigation of $16 \mathrm{~mm}$, using river water, was applied weekly up to four weeks after sowing and fortnightly thereafter until the wastewater treatments started. However, the pearl millet grew prolifically under the conditions prevalent in the trial and completed its life cycle on 2011-02-24, when only the second irrigation with diluted winery wastewater was applied during the 2011 harvest period. Therefore, it was sown approximately six weeks later (10 January) in 2012 and 2013.

\section{Fertiliser applied}

The amounts of fertiliser applied to supply nutrients to the two cover crop species are shown in Table 2. Phosphate (P) was applied just before seedbed preparation on two occasions, namely March 2010 and the end of November 2011 for oats and pearl millet respectively. This was done to ensure a sufficient supply of P to the cover crops in the top soil layer. Both species received N during the two- to four-leaf stages as proposed by Van Huyssteen and Van Zyl (1984). In contrast to the 2010 and 2011 seasons, an additional $28 \mathrm{~kg} / \mathrm{ha}$ of $\mathrm{N}$ was applied just after the oats were sown during the fourth week of April 2012 to prevent a N deficit from developing in the top soil due to the incorporation of the pearl millet residues just before the oats were sown, as well as to compensate for the significant amounts of $\mathrm{N}$ removed by the pearl millet. To avoid excessive vegetative growth of the grapevines, this was not repeated in April 2013. Both the $\mathrm{P}$ and $\mathrm{N}$ were broadcast by hand.

\section{Weed control}

Full-surface post-emergence weed control was achieved at the end of September (after the oats had been slashed and harvested) by applying glyphosate at a rate of $1.44 \mathrm{~kg} / \mathrm{ha}$ by means of a covered sprayer. During the grapevine growing season, post-emergence weed control was achieved in the vine row by applying paraquat at a rate of $1.25 \mathrm{~kg} / \mathrm{ha}$ with knapsack sprayers as soon as the weeds reached a height of approximately $300 \mathrm{~mm}$.

\section{Measurements}

Cover crop growth

Cover crop dry matter production (DMP) was determined from a sample by harvesting the above-ground vegetative growth in a $0.5 \mathrm{~m}^{2}$ sub-plot randomly chosen in each plot (replicate). Samples were oven-dried for $48 \mathrm{~h}$ at $70{ }^{\circ} \mathrm{C}$. In 2010 the oats were slashed and harvested twice, namely 2010-06-29 and 2010-09-29, whereas in the following three years it was harvested only during September. Pearl millet was harvested twice in a season throughout the study. As no harvester small enough to be utilised in a vineyard was available, the cover crops were slashed full surface directly after sampling. Thereafter the whole surface was raked and the residues removed to prevent the mineral elements absorbed by the above-ground growth from being returned to the soil through decomposition.

\section{Mineral element content of the cover crops}

A sample was collected by harvesting the above-ground growth in a $0.5 \mathrm{~m}^{2}$ sub-plot randomly chosen in each experimental plot. The samples were analysed by a commercial laboratory (BEMLAB, Somerset West) for macro- and micro-elements throughout the study and for heavy metals during the 2010/2011 season. After sampling, the leaf blades were washed with a Teepol ${ }^{\circledR}$ solution, rinsed with de-ionised water and dried overnight in an oven at $70^{\circ} \mathrm{C}$. The dried leaves were then milled and ashed at $480^{\circ} \mathrm{C}$, shaken up in a 50:50 hydrochloric acid $(\mathrm{HCl})(32 \%)$ solution for extraction through filter paper (Campbell \& Plank, 1998; Miller, 1998). The $\mathrm{K}$, magnesium $(\mathrm{Mg})$, calcium (Ca), Na, boron $(\mathrm{B})$, iron $(\mathrm{Fe})$, zinc $(\mathrm{Zn})$, copper $(\mathrm{Cu})$ and manganese $(\mathrm{Mn})$ content of the extracts was measured with a Varian ICPOES optical emission spectrometer (Agilent Technologies).

The total $\mathrm{N}$ content of the ground leaves was determined by a commercial laboratory (BEMLAB, Somerset West) through total combustion in a Leco $\mathrm{N}$-analyser (Leco corporation, USA). For analysis of cadmium (Cd), chromium

\section{TABLE 2}

The amounts of phosphate $(\mathrm{P})$ and nitrogen $(\mathrm{N})$ applied to supply in the needs of the two cover crop species.

\begin{tabular}{ll}
\hline Date & $\begin{array}{l}\text { Fertiliser applied } \\
(\mathrm{kg} / \mathrm{ha})\end{array}$ \\
\hline $2009 / 2010$ harvest season: & \\
$2010-03-30$ & $40.5 \mathrm{P}$ \\
$2010-06-17$ & $28.0 \mathrm{~N}$ \\
$2010 / 2011$ harvest season: & \\
$2010-12-07$ & $28.0 \mathrm{~N}$ \\
$2011-05-12$ & $28.0 \mathrm{~N}$ \\
$2011 / 2012$ harvest season: & \\
$2011-11-30$ & $40.5 \mathrm{P}$ \\
$2012-01-10$ & $28.0 \mathrm{~N}$ \\
$2012-04-24$ & $28.0 \mathrm{~N}$ \\
$2012-06-06$ & $28.0 \mathrm{~N}$ \\
$2012 / 2013$ harvest season: & \\
$2013-02-05$ & $28.0 \mathrm{~N}$ \\
$2013-05-31$ & $28.0 \mathrm{~N}$ \\
\hline
\end{tabular}


$(\mathrm{Cr})$, lead $(\mathrm{Pb})$, arsenic (As) and mercury $(\mathrm{Hg}), 5 \mathrm{~g}$ of the dried and milled leaves were digested with $20 \mathrm{~mL} \mathrm{HNO}_{3}$ $(55 \%)$ and $5 \mathrm{~mL}$ hydrogen peroxide $(30 \%)$ on a heated sandbed $\left(180^{\circ} \mathrm{C}\right)$ until the solution turned clear, after which it was filtered using Whatman filter paper (Whatman 2). The heavy metal content of the extract was measured with the Varian ICP-OES optical emission spectrometer at different wavelengths for the different metals, i.e. Cd: $214.4 \mathrm{~nm}$; Cr: 267.7 nm; Pb: 2204 nm; As: 193.7 nm; and HG: 184.9 nm, as described in Chapman and Pratt (1961).

\section{Amounts of the macro-elements intercepted by pearl millet and oats}

The amounts of $\mathrm{K}, \mathrm{Mg}, \mathrm{Ca}, \mathrm{P}$ and $\mathrm{N}$ intercepted by the cover crops were estimated by employing the following formula:

$\mathrm{A}=\mathrm{DMP} \times 10^{3} \times \mathrm{B} \times 0.8$

where $\mathrm{A}$ is the amount of the element intercepted by the cover crops in $\mathrm{kg} / \mathrm{ha}$, DMP is the amount of dry matter produced in $\mathrm{t} / \mathrm{ha}, 1000$ is the conversion factor from $\mathrm{t} / \mathrm{ha}$ to $\mathrm{kg} / \mathrm{ha}, \mathrm{B}$ is the amount of the element present in the fibre of the cover crops expressed as a percentage, and 0.8 is the percentage of the total surface area (1) covered by the interception crop.

The amount of $\mathrm{Na}$ intercepted by the cover crops was estimated by employing the following formula:

$\mathrm{A}=\operatorname{DMP} \times 10^{3} \times\left(\mathrm{C} / 10^{6}\right) \times 0.8$

where $\mathrm{C}$ is the amount of Na present in the fibre of the cover crop in $\mathrm{mg} / \mathrm{kg}$, and $10^{6}$ is the conversion factor from $\mathrm{mg} / \mathrm{kg}$ to $\mathrm{kg} / \mathrm{kg}$. The other symbols/factors are the same as those used in equation one.

\section{Statistical analyses}

The experiment was a complete randomised block design with nine treatments replicated three times. The experiment was repeated for four consecutive seasons. DMP and the analysis of the above-ground growth were measured from samples collected randomly within each experimental plot. The data were tested for normality (Shapiro \& Wilk, 1965), found to be acceptably normally distributed and subjected to analysis of variance. Analyses of variance were performed for each season separately, using SAS (SAS, 1990). Student's $t$ least significant difference (LSD) was calculated at the 5\% and $10 \%$ significance levels to facilitate comparison between treatment means.

\section{RESULTS AND DISCUSSION \\ Oats \\ Yield}

The irrigations applied from March to May 2010 with winery wastewater diluted to different COD levels had no effect on the vegetative growth of the oats from 2010-04-14 to 201009-29 (Table 1). However, the winery-enriched water applied from 2011-02-01 (one month before seedbed preparation) to 2011-04-14 (one week after the oats were sown) improved the performance of the oats in T4, T6 and T7 compared to T1. This supports the results of Rusan et al. (2007) in a trial in which barley was irrigated with municipal wastewater. The DMP of the oats in the other treatments irrigated with winery-enriched water also tended to be higher than that of T1. This could be attributed to the winery wastewater supplying additional $\mathrm{K}$ and $\mathrm{N}$ to the oats during the first six weeks of growth. During both seasons, the DMP of oats was similar to that reported for a sandy soil near Lutzville (313'ㅅ, 18 $52^{\circ}$ 'E) (Fourie et al., 2005), a sandy loam soil near Stellenbosch (33⒌ $\left.55^{\prime} \mathrm{S}, 1^{\circ} 52^{\prime} \mathrm{E}\right)$ (Fourie et al., 2006a)

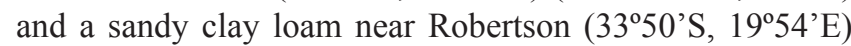
(Fourie et al., 2006b).

Despite the fact that the oats were established approximately three weeks later in 2012 (2012-04-26 vs. 2011-04-07) and harvested approximately three weeks earlier (2012-09-04 vs. 2011-09-26), the oats produced on average $42 \%$ more in 2012 than in 2011 (Table 1). This was attributed to the additional $28 \mathrm{~kg} / \mathrm{ha} \mathrm{N}$ applied on $2012-04-24$ just after the oats were sown. In contrast to 2011, the winery wastewater applied from March to May 2012 did not improve the performance of the oats in the treatments irrigated with diluted winery wastewater (T2 to T9) in comparison with the treatment irrigated with river water (T1). This trend was attributed to the additional $\mathrm{N}$ applied just after the seeds were sown, probably eliminating the effect of the $\mathrm{N}$ in the diluted winery wastewater. Although the DMP did not differ significantly between treatments, the DMP in T2 and T9 was approximately $41 \%$ less than that measured in T1. The reason for this is not clear. Similar to 2012, the DMP of oats measured on 2013-09-11 did not differ between treatments and exceeded that of 2011. It seems that some of the $\mathrm{N}$ applied on 2013-02-05 (compared to 2010-12-07) may have been available to the oats during the first six weeks of growth, overriding the effect of the $\mathrm{N}$ in the diluted winery wastewater.

\section{Chemical composition}

Throughout the study, the levels of $\mathrm{K}$ in the above-ground growth did not differ between treatments (data not shown). During 2010, the mean K content was $2.76 \pm 0.25 \%$ after 106 days of growth (2010-07-29), which was similar to that reported by Bezuidenhout (2012). The mean percentage $\mathrm{K}$ present in the leaves harvested on 2010-09-29 (second harvest) was $1.59( \pm 0.21)$. This is an indication that oats take up more $\mathrm{K}$ during the early growing stages, which supports the results of Palazzo (1981). During September 2011, September 2012 and September 2013, the mean K contents amounted to $1.47 \pm 0.24 \%, 2.00 \pm 0.34 \%$ and $1.47 \pm$ $0.15 \%$ respectively. The levels observed in the current study were comparable to those reported by Whitehead (2000, in Arienzo et al., 2009a) to be typical for grasses.

Similar to K, Na did not respond to the level of winery wastewater dilution in 2010 and 2011 (data not shown). The mean $\mathrm{Na}$ of the July harvest $(187 \pm 46 \mathrm{mg} / \mathrm{kg})$ was comparable to the values reported by Bezuidenhout (2012), but nearly $40 \%$ less than that of the September harvest (306 \pm $109 \mathrm{mg} / \mathrm{kg}$ ). Although the results of the current study indicate that oats accumulate more $\mathrm{Na}$ during the later growing stages, Bezuidenhout reported a higher uptake during the first seven weeks after emergence. These contradictory trends indicate that the uptake of $\mathrm{Na}$ by oats needs clarification. Although the $\mathrm{Na}$ content differed significantly between some treatments in 2012 and 2013 (data not shown), there were no consistent trends that could be related to the level of dilution. During 
2011, 2012 and 2013, the mean Na contents amounted to $415 \pm 51 \mathrm{mg} / \mathrm{kg}, 1941 \pm 708 \mathrm{mg} / \mathrm{kg}$ and $1078 \pm 598 \mathrm{mg} / \mathrm{kg}$ respectively, indicating an increase over time, especially from 2011 to 2012. Although the level of $\mathrm{Na}$ declined from 2012 to 2013 , it remained higher than the values reported for 2011. This trend was attributed to higher levels of Na present in the top layers of the soil compared to the baseline values (Howell \& Myburgh, 2014).

Although the $\mathrm{N}$ content of the oats did differ between treatments in the 2010 (29 July), 2011 and 2013 seasons, no definite trends were observed (data not shown). The percentage N measured in the leaves of oats during July 2010, September 2010, September 2011, September 2012 and September 2013 amounted to $2.05 \pm 0.29 \%, 1.32 \pm 0.17 \%$, $1.44 \pm 0.23 \%, 1.55 \pm 0.23 \%$ and $1.13 \pm 0.14 \%$ respectively. This was between $16 \%$ and $70 \%$ lower than that reported by Bezuidenhout (2012). Compared to the other seasons, the $\mathrm{N}$ applied just after sowing during 2012 did not affect the $\mathrm{N}$ levels in the leaves.

The levels of $\mathrm{P}$ did not differ between treatments or seasons throughout the study, despite the fact that additional P was applied during March 2010 and November 2011 (data not shown). The percentage $\mathrm{P}$ measured in the leaves of oats during July 2010, September 2010, September 2011, September 2012 and September 2013 amounted to $0.41 \pm$ $0.03 \%, 0.35 \pm 0.05 \%, 0.34 \pm 0.04 \%, 0.30 \pm 0.03 \%$ and 0.24 $\pm 0.01 \%$, respectively. These results were comparable to the levels reported by Bezuidenhout (2012).

Both the $\mathrm{Ca}$ and $\mathrm{Mg}$ contents of the oats did not differ between treatments throughout the study (data not shown). The percentage $\mathrm{Ca}$ measured in the leaves of oats during July 2010, September 2010, September 2011, September 2012 and September 2013 amounted to $0.32 \pm 0.03 \%, 0.17$ $\pm 0.02 \%, 0.16 \pm 0.01 \%, 0.16 \pm 0.03 \%$ and $0.17 \pm 0.01 \%$ respectively. This was $50 \%$ lower than those reported by Bezuidenhout (2012). The percentage Mg measured in the leaves of oats during July 2010, September 2010, September 2011, September 2012 and September 2013 amounted to $0.18 \pm 0.02 \%, 0.15 \pm 0.02 \%, 0.22 \pm 0.01 \%, 0.15 \pm 0.03 \%$ and $0.13 \pm 0.01 \%$ respectively. This was $40 \%$ lower than those reported by Bezuidenhout (2012). The levels of $\mathrm{Ca}$ and $\mathrm{Mg}$ in crops growing in the Western Cape tend to be lower than those reported for other regions due to the fact that the $\mathrm{Ca}$ and $\mathrm{Mg}$ content of soils in the Western Cape generally tend to be lower (W.J. Conradie, personal communication, 2014). No specific trends were observed in the present study as far as the micro-elements were concerned (data not shown).

\section{Pearl millet}

Yield

The winery wastewater applied in February 2011 did not affect the growth of pearl millet negatively (Table 3 ). The pearl millet grew prolifically and, despite being slashed and harvested on 2011-01-12, went into the reproductive phase earlier than anticipated, namely mid-February 2011. During the first 50 days of growth, between $1.47 \mathrm{t} / \mathrm{ha}$ and $2.76 \mathrm{t} / \mathrm{ha}$ of fibre was produced, whilst more than $7 \mathrm{t} /$ ha was produced during the following 43 days. Although the DMP achieved in this study was much lower than that reported by Ayoub et al. (2009), it was still sufficient to allow pearl millet to function as a catch crop. To prevent the species from completing its life cycle too early, as well as to minimise competition with the grapevines for nutrients, it was sown on 10 January (six weeks later) during the following two seasons (2011/2012 and 2012/2013). Although pearl millet was established later, the first harvest (2012-03-01) still occurred one week before the first irrigation with winery wastewater could be applied. This harvest was executed to ensure that pearl millet remained in the vegetative phase for a longer period of time, as well as to prevent the upright growing interception crop from hampering the picking of the grapes. Another reason was that the grapes in the region ripened later compared to the previous season, resulting in sufficient amounts of winery wastewater only becoming available one month later.

Similar to 2011, the DMP did not differ between treatments (Table 3), indicating that the winery wastewater had no effect on the performance of pearl millet. The DMP of the second harvest (after a re-growth period of 54 days) was higher than that of the first harvest (after a growing period of 49 days), irrespective of the treatments applied. This supports the trend observed in the previous season. During 2012, the average growth rate of pearl millet up to the first harvest was $31.7 \mathrm{~kg}$ dry matter/ha/day, compared to $81.8 \mathrm{~kg}$ dry matter/ ha/day between the first and second harvests. Despite the fact that seasonal variation makes it extremely difficult to determine the optimal seeding date for the summer-growing interception crop, the pearl millet remained in the vegetative phase, with the peak growth period occurring when $91 \%$ of the winery wastewater was applied, namely 2012-03-08 to 2012-04-18. Although the trends were similar during both seasons, the average DMP of pearl millet declined from $10.42 \mathrm{t} /$ ha in the $2010 / 2011$ season to $5.97 \mathrm{t} / \mathrm{ha}$ in the $2011 / 2012$ season. This decline occurred despite the fact that the growth period was 10 days longer in 2011/2012 than in 2010/2011. Sowing 48 days later than the generally accepted seeding date could have caused this decline.

With the exception of T3 and T9, the dry matter produced by pearl millet during 2013 was more than in the previous season (Table 3 ). The diluted winery wastewater applied on 2013-02-15 and 2013-02-27 in treatments T2 to T9 had no effect on the performance of the pearl millet compared to T1 (first harvest 2013-03-05). The fertiliser $\mathrm{N}$ applied on 5 February helped to ensure acceptable cover crop growth in all the treatments. The cover crop dry matter produced in T2, T3, T6, T7 and T9 from 2013-03-05 to 2013-04-23 exceeded that of T1, whilst in the case of T4, T5 and T8 it was significantly higher. The total seasonal growth of pearl millet showed a similar trend, with the dry matter produced in T4, T5, T6, T7 and T8 being significantly higher than that of T1. This is an indication that the pearl millet did benefit from the amounts of macro- and micro-elements applied by means of the diluted winery wastewater used for irrigations from February to April 2013 on this sandy soil. This supports the data of Rusan et al. (2007) in a trial in which barley was irrigated with municipal wastewater.

\section{Chemical composition}

With the exception of the harvest on 2011-02-24, the percentage $\mathrm{K}$ in the above-ground growth of pearl millet did not differ between treatments (data not shown). Despite 

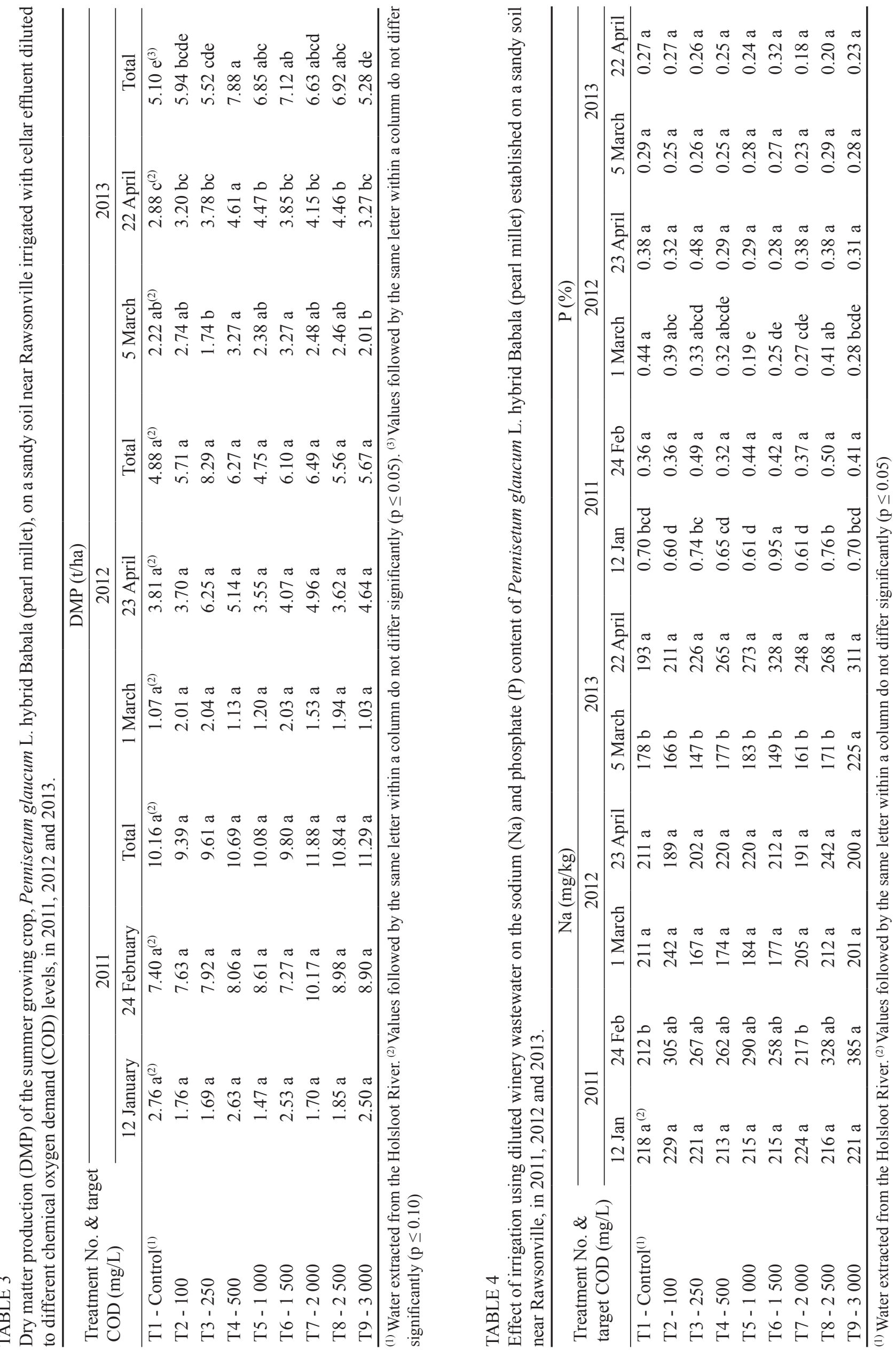
the differences observed for the harvest on 2011-02-24, no definite trends could be detected. On 2011-01-12, 201102-24, 2012-03-01, 2012-04-23, 2013-03-05 and 2012$04-22$, the mean $\mathrm{K}$ contents amounted to $5.33 \pm 0.20 \%$, $2.58 \pm 0.64 \%, 3.52 \pm 0.39 \%, 1.94 \pm 0.57 \%, 2.61 \pm 0.17 \%$ and $2.13 \pm 0.21 \%$, respectively. Throughout the study, the concentration of $\mathrm{K}$ during the first harvest of a season tended to be higher than that of the second harvest. This supports the results of Palazzo (1981). The levels of K measured during the second harvest corresponded with those reported by Whitehead (2000, in Arienzo et al., 2009a), while those measured during the first harvest were higher than the range reported for the species in general (Whitehead, 2000, in Arienzo et al., 2009a). This is an indication that pearl millet is a heavy $\mathrm{K}$ consumer during its early growing stages.

The Na levels in T9 were higher than those of T1 during the harvests of 2011-02-24 and 2013-03-05 (Table 4). The percentage $\mathrm{Na}$ in all the treatments irrigated with diluted winery wastewater also tended to be higher than in $\mathrm{T} 1$ at the 2011-02-24 and 2013-04-22 harvests. With the exception of T1 in 2011 and 2012, as well as T2, T7 and T9 in 2012, the Na levels tended to increase from the first to the second harvest. These results indicate that the diluted winery wastewater did affect Na uptake by pearl millet, albeit very slightly.

Throughout the study, irrigation with diluted winery wastewater did not affect the $\mathrm{N}$ status of pearl millet (data not shown). On 2011-01-12, 2011-02-24, 2012-03-01, 2012-04-23, 2013-03-05 and 2013-04-22, the mean $\mathrm{N}$ contents amounted to $3.04 \pm 0.28 \%, 1.02 \pm 0.0 .19 \%, 2.87$ $\pm 0.42 \%, 1.56 \pm 0.20 \%, 3.40 \pm 0.26 \%$ and $2.24 \pm 0.38 \%$, respectively. Throughout the study, the concentration of $\mathrm{N}$ during the first harvest of a season tended to be higher than that of the second harvest, indicating that pearl millet needs more $\mathrm{N}$ during its early growing stages.

With the exception of 2012-03-01, irrigation with diluted winery wastewater did not affect the P status of pearl millet (Table 4). The percentage P in the T5, T6, T7 and T9 treatments of the 2012-03-01 harvest was lower than that in $\mathrm{T} 1$. This occurred despite the fact that $40.5 \mathrm{~kg} / \mathrm{ha}$ of fertiliser $\mathrm{P}$ was broadcast in all the treatments on 2011-11-30, which ensured a sufficient supply of P to the interception crop (AlSuhaibani, 2011). The reason for the observed differences is not clear.

The percentage of $\mathrm{Ca}$ in the above-ground growth of pearl millet did not differ between treatments, except in the harvests on 2011-01-12 and 2012-03-01 (data not shown). Despite the differences observed, no definite trends could be detected. In both cases, the seasonal application of diluted winery wastewater had not yet occurred. Therefore, the differences could not be attributed to irrigation with winery wastewater. On 2011-01-12, 2011-02-24, 2012-03-01, 2012-04-23, 2013-03-05 and 2013-04-22, the mean Ca contents amounted to $0.70 \pm 0.10 \%, 0.41 \pm 0.06 \%, 0.60$ $\pm 0.16 \%, 0.39 \pm 0.04 \%, 0.72 \pm 0.08 \%$ and $0.53 \pm 0.08 \%$, respectively. Throughout the study, the concentration of $\mathrm{Ca}$ during the first harvest of a season tended to be higher than that of the second harvest.

Although the $\mathrm{Mg}$ levels present in the pearl millet harvested on 2011-01-12 differed significantly between treatments, no definite trends were observed for $\mathrm{Mg}$ throughout the study (data not shown).

The levels of macro- and micro-elements in the current study did not differ between treatments, thus supporting the results of Al-Jaloud et al. (1995), which indicated that wastewater irrigation did not increase the mineral concentrations of macro- and micro-elements in sorghum plants.

\section{Calculated amounts of elements removed by interception crops} April to September 2010

The amounts of $\mathrm{K}, \mathrm{P}, \mathrm{Ca}$ and $\mathrm{Mg}$ intercepted by oats did not differ between treatments (data not shown). A similar trend was observed for the amounts of $\mathrm{N}$ and $\mathrm{Na}$ intercepted from 14 April up to the first harvest (July). From 29 July to 29 September (second harvest), oats tended to remove more $\mathrm{N}$ from the treatments irrigated with diluted winery wastewater (T2 to T9) than from the treatment irrigated with water from the Holsloot River (Table 5). In the case of T6 and T7, the differences were significant. From the first to the second harvest, more $\mathrm{Na}$ was intercepted in $\mathrm{T} 3$ than in $\mathrm{T} 1$. Although not significant, this trend was also observed for $\mathrm{T} 2$ and $\mathrm{T} 5$ to T9. The observed trends were attributed to the fact that the oats in T2 to T9 tended to produce more dry matter than that in T1 (Table 1).

The average rate at which $\mathrm{N}$ was intercepted by oats from the seeding date to the first harvest amounted to $526 \mathrm{~g} / \mathrm{ha} /$ day compared to $348 \mathrm{~g} / \mathrm{ha} /$ day (34\% less) from the first harvest to the second harvest. This was attributed to the $28 \mathrm{~kg} / \mathrm{ha} \mathrm{N}$ applied 42 days after the oats were sown, making more $\mathrm{N}$ available to the cover crop. Although not as pronounced, a similar downward trend was observed in the average rate at which $\mathrm{P}$ was intercepted. In contrast to $\mathrm{N}$ and $\mathrm{P}$, the average rate at which $\mathrm{Na}$ was intercepted increased from $4.72 \mathrm{~g} / \mathrm{ha} /$ day (from the seeding date to first harvest) to $20.81 \mathrm{~g} / \mathrm{ha} /$ day (from the first to second harvest). Despite the $440 \%$ increase in the rate at which $\mathrm{Na}$ was intercepted, the amounts of $\mathrm{Na}$ removed by oats were still insignificant (Table 5).

\section{TABLE 5}

Calculated amounts of nitrogen $(\mathrm{N})$ and sodium $(\mathrm{Na})$ removed by Avena sativa L. cv. Pallinup (oats) from 2010-07-29 to 2010-09-29.

\begin{tabular}{lcc}
\hline Treatment no \& target & \multicolumn{2}{c}{ Calculated amount $(\mathrm{kg} / \mathrm{ha})$} \\
\cline { 2 - 3 } COD $(\mathrm{mg} / \mathrm{L})$ & $\mathrm{N}$ & $\mathrm{Na}$ \\
\hline $\mathrm{T} 1-$ Control $^{(1)}$ & $15 \mathrm{~b}^{(2)}$ & $0.99 \mathrm{bc}$ \\
$\mathrm{T} 2-100$ & $25 \mathrm{ab}$ & $1.19 \mathrm{bc}$ \\
$\mathrm{T} 3-250$ & $19 \mathrm{ab}$ & $2.43 \mathrm{a}$ \\
$\mathrm{T} 4-500$ & $18 \mathrm{ab}$ & $0.81 \mathrm{c}$ \\
$\mathrm{T} 5-1000$ & $18 \mathrm{ab}$ & $1.12 \mathrm{bc}$ \\
$\mathrm{T} 6-1500$ & $27 \mathrm{a}$ & $1.32 \mathrm{bc}$ \\
$\mathrm{T} 7-2000$ & $27 \mathrm{a}$ & $1.15 \mathrm{bc}$ \\
$\mathrm{T} 8-2500$ & $23 \mathrm{ab}$ & $1.03 \mathrm{bc}$ \\
$\mathrm{T} 9-3000$ & $22 \mathrm{ab}$ & $1.59 \mathrm{~b}$ \\
\hline
\end{tabular}

(1) Water extracted from the Holsloot River. ${ }^{(2)}$ Values followed by the same letter within a column do not differ significantly $(\mathrm{p} \leq 0.05)$. 


\section{October 2010 to September 2011}

The application of winery wastewater diluted to different COD levels did not have an effect on the amounts of N, K, $\mathrm{Na}, \mathrm{P}, \mathrm{Mg}$ and $\mathrm{Ca}$ that were removed by pearl millet and oats (Tables $6 \& 7$ ). However, the amounts removed by oats in T2 to $\mathrm{T} 9$ tended to be higher than that of T1. With the exception of K in T7 (Table 6) and P in T2 and T4 (Table 7), a similar trend was observed for pearl millet as far as $\mathrm{K}, \mathrm{Na}$ and $\mathrm{P}$ were concerned (Tables $6 \& 7$ ). The amounts of $\mathrm{Mg}$ and $\mathrm{Ca}$ removed by pearl millet in T4 to T9 also tended to be higher than that removed in T1 (Table 7). These trends were less prominent than those detected for oats. This was attributed to pearl millet receiving only two irrigations with diluted winery wastewater 24 days and four days before the end of its growing season, i.e. on 2011-02-01 and 2011-02-20.

The two crops combined intercepted more $\mathrm{N}, \mathrm{K}, \mathrm{P}, \mathrm{Mg}$ and $\mathrm{Ca}$ than those added by means of the winery wastewater and fertilisers, but very little $\mathrm{Na}$ (Tables 6 \& 7). The large amounts of $\mathrm{N}$ and $\mathrm{K}$ removed by pearl millet were attributed to the vigorous growth of the species (producing on average $163 \mathrm{~kg}$ of dry matter per hectare per day). In treatments T4 and treatments $\mathrm{T} 6$ to $\mathrm{T} 9$, oats removed more $\mathrm{N}$ than those applied by means of the winery wastewater and fertiliser. Oats intercepted too much $\mathrm{K}$ in treatments $\mathrm{T} 1$ to $\mathrm{T} 4$. The species alone, however, removed too little $\mathrm{K}$ in treatments T5 to T9. The potentially positive balance of $30 \mathrm{~kg} / \mathrm{ha}$ to $55.8 \mathrm{~kg} / \mathrm{ha}$ in T5 and T6, in which oats alone was used as a catch crop, may be beneficial on these sandy soils and serve as fertiliser for the grapevines. It seemed that pearl millet alone could remove acceptable amounts of $\mathrm{Ca}$ and $\mathrm{Mg}$, while oats on its own may have removed acceptable amounts of $\mathrm{P}$ in T9.

\section{October 2011 to September 2012}

Similar to the previous season, the diluted winery wastewater had no effect on the amounts of $\mathrm{N}, \mathrm{K}, \mathrm{Na}, \mathrm{P}, \mathrm{Mg}$ and $\mathrm{Ca}$ removed by oats (Tables $8 \& 9$ ). In contrast to the previous season, however, the amounts of $\mathrm{N}, \mathrm{Na}, \mathrm{P}, \mathrm{Mg}$ and $\mathrm{Ca}$ removed by oats in $\mathrm{T} 2$ to $\mathrm{T} 9$ tended to be lower than that in $\mathrm{T} 1$, with the exception of $\mathrm{N}$ in $\mathrm{T} 7$. No trends were detected for $\mathrm{K}$ (Table 8). The observed changes in the trends were attributed to the oats being sown 16 days later, which resulted in the species demand for nutrients probably peaking later than in the previous season, thereby reducing the effect that the winery wastewater might have had on nutrient uptake.

As far as pearl millet is concerned, the amounts of $\mathrm{Na}, \mathrm{Mg}$ and $\mathrm{Ca}$ removed did not differ between treatments (Tables $8 \& 9$ ). However, with the exception of T5, the $\mathrm{Na}$ and $\mathrm{Mg}$ removed from treatments $\mathrm{T} 2$ to $\mathrm{T} 9$ tended to be higher than those of T1. Although differences did occur between treatments as far as $\mathrm{P}$ was concerned, no trends were observed (Table 9). With the exception of T5, more N was removed by pearl millet from $\mathrm{T} 2$ to $\mathrm{T} 9$ than from $\mathrm{T} 1$ (Table 8). However, the $\mathrm{N}$ removed from $\mathrm{T} 5$ also tended to be higher than that from T1. More K was removed from T3, T4, T6, T7 and T8 than from $\mathrm{T} 1$. The $\mathrm{K}$ removed by pearl millet from $\mathrm{T} 2, \mathrm{~T} 5$ and $\mathrm{T} 9$ also tended to be higher than that removed from $\mathrm{T} 1$.

The pearl millet grew less vigorously during the 2011/2012 season than during the 2010/2011 season
(Table 3). The trend observed for oats was just the opposite (Table 1). This resulted in pearl millet removing less of the macro-nutrients, whilst oats removed more, compared to the previous season (Tables 6 to 9). Therefore, similar to the trends observed for the previous season, the two crops combined intercepted more $\mathrm{N}, \mathrm{K}, \mathrm{P}, \mathrm{Mg}$ and $\mathrm{Ca}$ than that added by means of the diluted wastewater and fertiliser, but less $\mathrm{Na}$. With the $84 \mathrm{~kg} / \mathrm{ha}$ of fertiliser $\mathrm{N}$ applied to promote cover crop growth during the 2011/2012 season, the amount of $\mathrm{N}$ added to the soil was similar to or more than that removed by pearl millet alone, with the exception of $\mathrm{T} 3$ and T7 (Table 8). As far as oats are concerned, the amounts added to the soil were similar or more than those removed, with the exception of T1, T4 and T7. This is an indication that additional fertiliser $\mathrm{N}$ needs to be applied where a catch crop is employed to maintain a balance. In the case of $\mathrm{K}$, the best balance was achieved with pearl millet alone in T8. The potentially positive balance of $37.5 \mathrm{~kg} / \mathrm{ha}$ to $59.7 \mathrm{~kg} / \mathrm{ha}$ in T8 and T9, where oats alone was used as a catch crop, may be beneficial on these sandy soils and serve as fertiliser for the grapevines. Excluding the fertiliser P applied, the best balance may be achieved in T9 by using either pearl millet or oats alone as a catch crop (Table 9). The amount of $\mathrm{Ca}$ extracted by pearl millet and the amount applied by means of the diluted winery wastewater was approximately the same for T4 and T5 (Table 9). The oats removed approximately the same amount of $\mathrm{Mg}$ that was applied via irrigation in all the treatments, while the interception by pearl millet was excessive.

\section{October 2012 to September 2013}

Similar to the 2010/2011 and 2011/2012 seasons, diluted winery wastewater had no effect on the amounts of $\mathrm{N}, \mathrm{K}$, $\mathrm{Na}, \mathrm{P}, \mathrm{Mg}$ and $\mathrm{Ca}$ removed by oats (Tables $10 \& 11$ ). The amounts of these macro-nutrients intercepted by oats from treatments $\mathrm{T} 2$ to $\mathrm{T} 9$ tended to be lower than those from $\mathrm{T} 1$, with the exception of $\mathrm{N}$ in $\mathrm{T} 5$ and T6, $\mathrm{K}$ in $\mathrm{T} 6$ and $\mathrm{T} 7, \mathrm{Na}$ in T3, as well as P in T4 and T7. With the exception of $\mathrm{K}$, these trends supported those observed during the 2011/2012 season.

The effect that the treatments had on the amounts of macro-nutrients removed by pearl millet supported the trends observed during the 2011/2012 season, with the exception of $\mathrm{N}$ (Tables 8 to 11). In contrast to the previous two seasons, no definite pattern could be observed for the interception of $\mathrm{N}$ by pearl millet (Table 10). Pearl millet intercepted more $\mathrm{Mg}$ in T4 than T1 and also tended to remove more $\mathrm{Mg}$ from T2, T5, T6, T7 and T8 (Table 11).

Similar to the trend observed for the previous two seasons, the two cover crops combined intercepted more N, $\mathrm{K}, \mathrm{P}, \mathrm{Mg}$ and $\mathrm{Ca}$ than those applied via the diluted winery wastewater and fertiliser, but intercepted very little $\mathrm{Na}$ (Tables $10 \& 11$ ). With the $56 \mathrm{~kg}$ of fertiliser $\mathrm{N}$ applied to promote cover crop growth, the amounts of $\mathrm{N}$ added to the soil were similar to that removed by oats in T2, T3, T8 and T9 (Table 10). However, the $\mathrm{N}$ removed by pearl millet exceeded the $\mathrm{N}$ applied via the winery wastewater and fertiliser. The amounts of $\mathrm{K}$ removed by pearl millet in T7 and T8 were similar to the amounts added to the soil by irrigation with diluted winery wastewater. This was also 

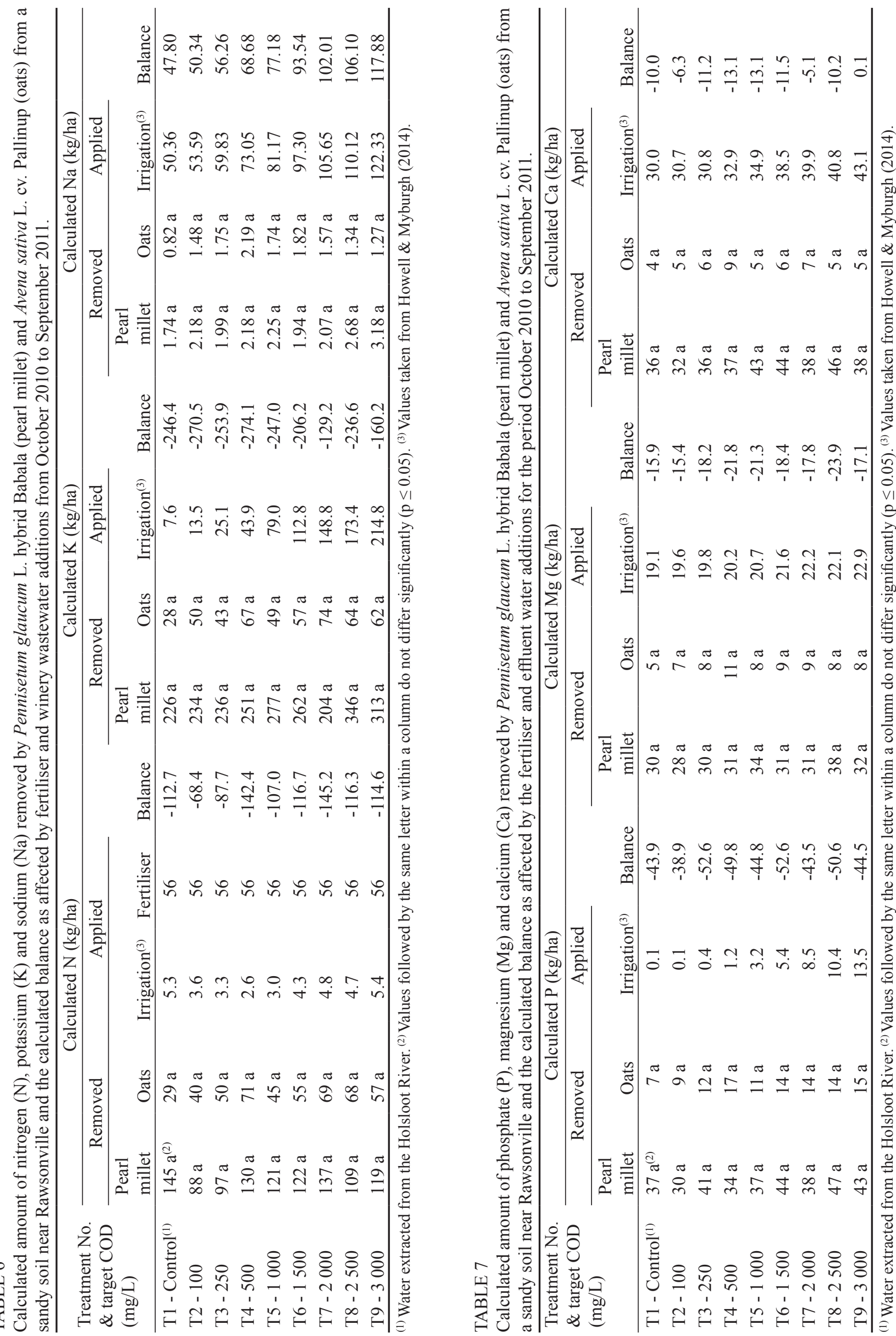

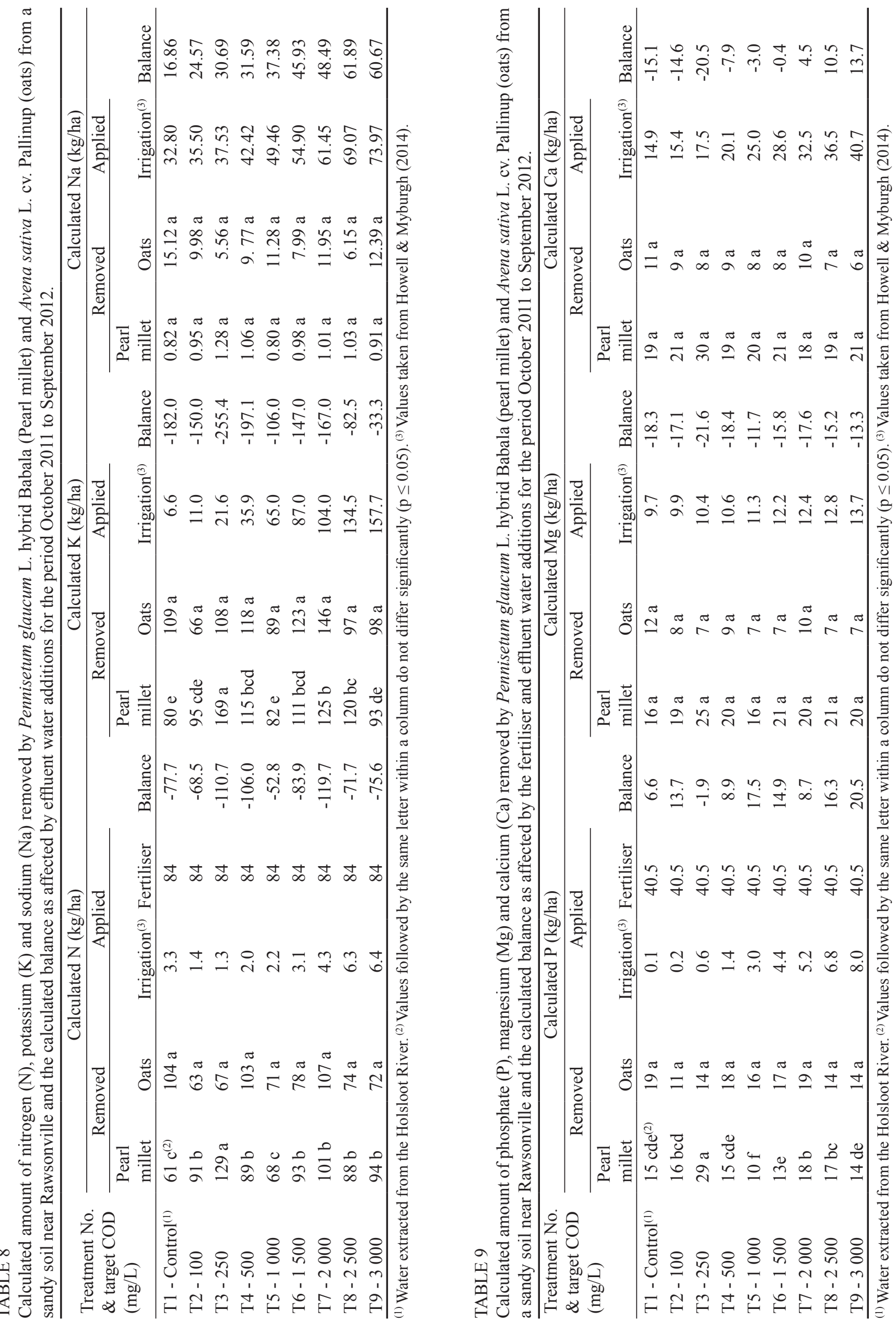

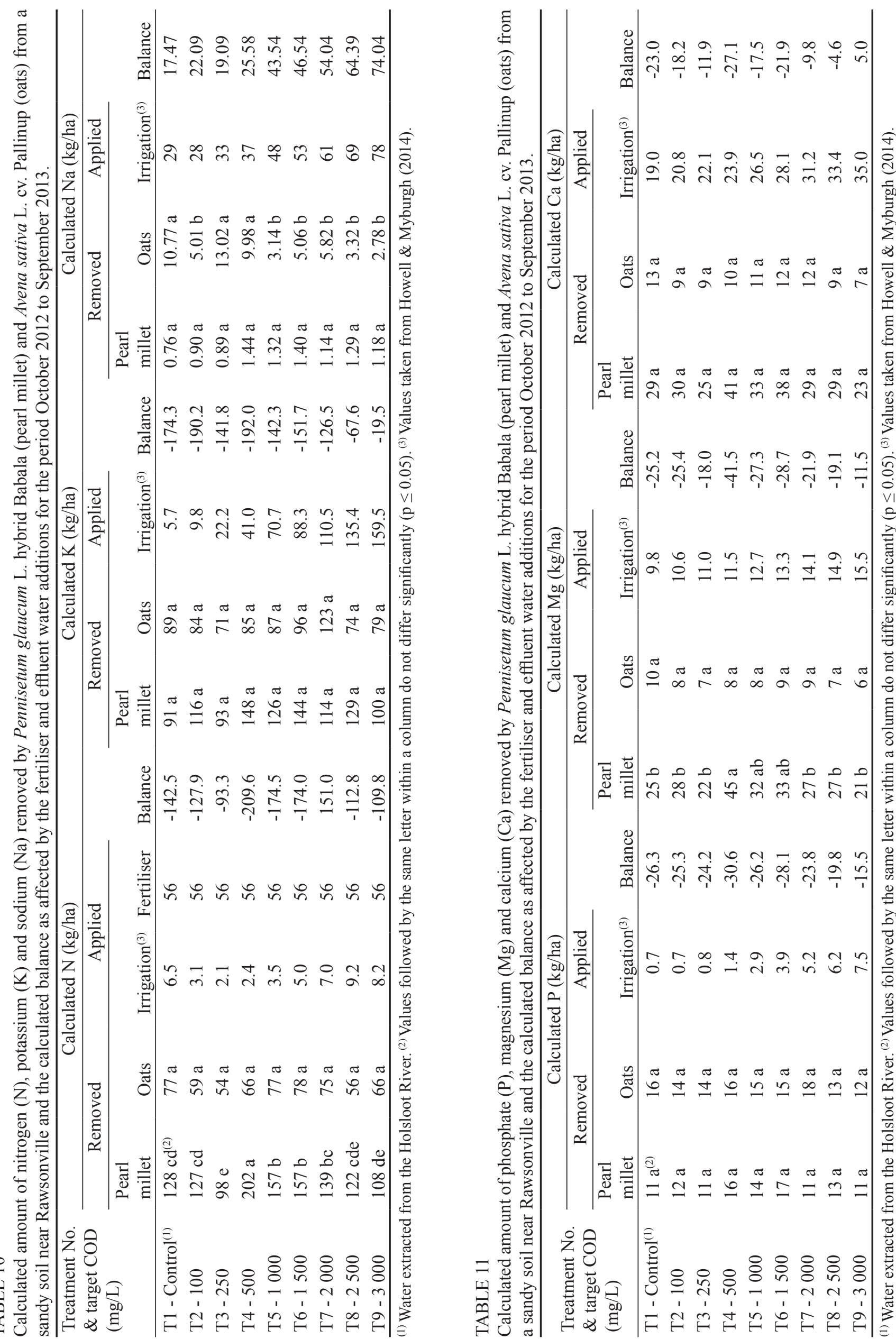
observed for Ca in $\mathrm{T} 7$ to T9 (Table 11).

The above-mentioned results indicate that the two species should not be used as follow-up interception crops. In an effort to balance the nutrients added with the nutrients extracted, only one of the species should be used as an interception crop. The exclusion of oats as interception crop (not harvesting and removing it from the vineyard) whilst employing only pearl millet as an interception crop could be a sustainable practice where winery wastewater diluted to CODs of between 2000 (T7) and 2500 (T8) is used for irrigating grapevines. To neutralise the $\mathrm{N}$ removed by pearl millet, an average of $120 \mathrm{~kg} / \mathrm{ha}$ of fertiliser $\mathrm{N}$ needs to be applied. This will increase the input cost by R2 311/ha. As in the case of $\mathrm{N}$, the deficits created by the extraction of excess $\mathrm{P}$ by pearl millet can be corrected by fertilising with approximately $9.6 \mathrm{~kg} / \mathrm{ha} \mathrm{P}$ at a cost of R504/ha. However, with an average of 433 bales per hectare being produced by pearl millet, an income of R45 per bale will amount to R19 485 .

\section{CONCLUSIONS}

In general, the DMP, element content and the amounts of the elements intercepted by both oats and pearl millet were not affected by the application of winery wastewater. Using both species to intercept the elements deposited by the winery wastewater resulted in more $\mathrm{N}, \mathrm{K}, \mathrm{P}, \mathrm{Mg}$ and $\mathrm{Ca}$ being removed from the soil than was applied by means of the winery wastewater and fertiliser. However, the amounts of $\mathrm{Na}$ removed were insignificant. The wine industry therefore should consider using K-based cleaning agents rather than Na-based cleaning agents, as especially pearl millet showed the ability to intercept large amounts of K.

Managing oats as a cover crop (not harvesting and removing it from the vineyard), whilst employing only pearl millet as an interception crop during the period when winery wastewater is likely to be applied to the vineyard, could be a sustainable practice. It seems, however, that the COD level of the winery wastewater should preferably be between $2000 \mathrm{mg} / \mathrm{L}$ and $2500 \mathrm{mg} / \mathrm{L}$. The growing season of the oats being shortened by as much as six weeks due to the pearl millet being grown during harvest did not affect the vegetative growth of the species negatively. The oats therefore should produce enough fibre to create quality summer mulches for pre-véraison weed control in vineyards.

As interception crop in grapevines, pearl millet should be sown in early January to help ensure its growth peaks when the winery wastewater needs to be applied and that the species does not complete its life cycle too early. By doing this, competition between pearl millet and the grapevines for $\mathrm{N}$ and $\mathrm{P}$ also will be minimised. Although an additional expense of approximately R2 800 was required for the fertiliser that was applied to compensate for the excess $\mathrm{N}$ and $\mathrm{P}$ intercepted by pearl millet, the potential income of R19 485 more than compensates for this.

As the use of an interception crop in the disposal of winery wastewater is a financially viable option, the use of N-fixers with a spreading habit as interception crops in vineyards irrigated with winery wastewater should be researched. The possibility of using species normally planted for grazing should also be investigated.

\section{LITERATURE CITED}

Albassam, B.A., 2001. Effect of nitrate nutrition on growth and nitrogen assimilation of pearl millet exposed to sodium chloride stress. J. Plant Nutr. $24,1325-1335$

Al-Jaloud, A.A., Hussain, G., Al-Saati, A.J. \& Karimulla, S., 1995. Effect of wastewater irrigation on the mineral composition of corn and sorghum plants in a pot experiment. J. Plant Nutr. 18, 1677-1692.

Al-Suhaibani, N.A., 2011. Better forage and grain yield quality of pearl millet (Pennisetum glaucum L.) under different irrigation water supplies and plant densities. World Appl. Sci. J. 15(8), 1136-1143.

Arienzo, M., Christen, E.W., Quayle, W. \& Kumar, A., 2009a. A review of the fate of potassium in the soil-plant system after land applications of wastewaters. J. Hazard. Materials 164, 415-422.

Arienzo, M., Christen, E.W., Quayle, W. \& Kumar, A., 2009b. Irrigating with winery wastewater? Developing soil stability thresholds and managing total cations. Aust. N. Z. Grapegrow. \& Winemak. October, 86-88.

Ayoub, M., Nadeem, M.A., Tahir, M., Ibrahim, M. \& Aslam, M.N., 2009. Effect of nitrogen application and harvesting intervals on forage yield and quality of pearl millet (Pennisetum americanum L.). Pak. J. Life Soc. Sci. $7,185-189$

Bezuidenhout, S.R., 2012. The influence of two cover crop species on the growth of Zea mays and Cyperus esculentus. PhD dissertation, University of Pretoria, Private Bag X20, 0028 Hatfield (Pretoria), South Africa.

Blümmel, M., Zerbini, E., Reddy, B.V.S., Hash, C.T. Bidinger, F. \& Khan, A.A., 2003. Improving the production and utilization of sorghum and pearl millet as livestock feed: Progress towards dual-purpose genotypes. Field Crops Res. 84, 143-158.

Busi, R. \& Powles S.B., 2011. Reduced sensitivity to paraquat evolves under selection with low glyphosate doses in Lolium rigidum. Agronomy Sust. Developm. 31, 525-531.

Cameron, K.C., Rate, A.W., Noonan, M.J., Moore, S., Smith, N.P. \& Kerr, L.E., 1996. Lysimeter study of the fate of nutrients following subsurface injection and surface application of dairy pond sludge to pasture. Agric. Ecosys. Environ. 58, 187-197.

Campbell, C.R. \& Plank, C.O., 1998. Preparation of plant tissue for laboratory analysis. In: Y.P. Kalra (ed). Handbook of reference methods for plant analysis. CRC Press, Boca Raton.

Chapman, H.D. \& Pratt, P.F., 1961. Methods of analysis for soils, plants and waters. Univ. California Div. Agr. Sci., Riverside, CA.

Fourie, J.C., Louw, P.J.E. \& Agenbag G.A., 2001. Effect of seeding date on the performance of grasses and broadleaf species evaluated for cover crop management in two wine grape regions of South Africa. S. Afr. J. Plant \& Soil 18, 118-127.

Fourie J.C., Louw P.J.E. \& Agenbag, G.A., 2005. Cover crop management in a Sauvignon blanc/Ramsey vineyard in the semi-arid Olifants River Valley, South Africa. 1. Effect of management practices on selected grass and broadleaf species. S. Afr. J. Enol. Vitic. 26, 140-146.

Fourie, J.C., Louw, P.J.E. \& Agenbag, G.A., 2006a. Cover crop management in a Chardonnay/99 Richter vineyard in the Coastal wine grape region, South Africa. 1. Effect of two management practices on selected grass and broadleaf species. S. Afr. J. Enol. Vitic. 27, 167-177.

Fourie, J.C., Louw, P.J.E. \& Calitz, F.J., 2006b. Effect of seeding date on the performance of grasses and broadleaf species evaluated for cover crop management in the Breede River Valley wine grape region of South Africa. S. Afr. J. Enol. Vitic. 27, 8-14 
Howell, C.L. \& Myburgh, P.A., 2014. Effect of irrigation with diluted winery wastewater on soil chemical status. In: Myburgh, P.A. \& Howell, C.L. (eds). The impact of wastewater irrigation by wineries on soils, crop growth and product quality. WRC Report K5/1881/14.

Howell, C.L., Myburgh, P.A. \& Lategan. E.L., 2014. Water quality, irrigation volumes and amount of elements applied via wastewater irrigation. In: Myburgh, P.A. \& Howell, C.L. (eds). The impact of wastewater irrigation by wineries on soils, crop growth and product quality. WRC Report K5/1881/14

Khan, M.A., Shaukat, S.S., Shahzad, A. \& Arif, H., 2012. Growth and yield responses of pearl millet (Pennisetum glaucum (L.) R. Br.) irrigated with treated effluent from waste stabilization ponds. Pak. J. Bot. 44, 905-910.

Krishnamurthy, L., Serraj, R., Rai, K.N., Hash, C.T. \& Dakheel, A.J., 2007. Identification of pearl millet (Pennisetum glaucum (L.) R. Br.) lines tolerant to soil salinity. Euphytica 158, 179-188.

Laurenson, S., Bolan, N.S., Smith, E. \& McCarthy, M., 2012. Review: Use of recycled wastewater for irrigating grapevines. Aust. J. Grape Wine Res. $18,1-10$.

Lagoudi, A., Spanos, I., Barafaka, S., Founda, K., Devekou, O. \& Tsikos, I., 2004. Review on winery waste management technologies. Dionysos report LIFE/03 ENV/GR/000223. Environment LIFE Programme, European Commission.

Leske, P.A., Sas, A.N., Coulter, A.D., Stockley, C.S., \& Lee, T.H., 1997. The composition of Australian grape juice: Chloride, sodium and sulphate ions. Aust. J. Grape \& Wine Res. 3, 26-30.

McCarthy, M.G., 1981. Irrigation of grapevines with sewage effluent. 1. Effects on yield and petiole composition. Am. J. Enol. Vitic. 32, 189-196.

Mengel, K., Kirkby, E.A., Kosegarten, T. \& Appel, T., 2001 (5 $5^{\text {th }}$ ed). Principles of plant nutrition. Kluwer Academic Publishers, Dordrecht.

Miller, R.O., 1998. High temperature oxidation: Dry ashing. In: Y.P. Kalra (ed). Handbook of reference methods for plant analysis. CRC Press, Boca Raton.

Mulidzi, A.R., 2005. Monitoring performance of constructed wetlands in California. Wineland, May, 85-87.

Mulidzi, A.R., 2008. Cost of a constructed wetland at Goudini Distillery. Wynboer, February, 66-67.

Mulidzi, R., Laker, G., Wooldridge, J. \& Van Schoor, L., 2009. Seasonal variation and differences between wineries. Wynboer Technical Yearbook 2009/2010, 58-61.

Myburgh, P.A., Lategan. E.L. \& Howell, C.L., 2014. Experiment layout, infrastructure for augmenting winery wastewater and preliminary results. In: Myburgh, P.A. \& Howell, C.L. (eds), The impact of wastewater irrigation by wineries on soils, crop growth and product quality. WRC Report K5/1881/14.
Neilsen, G.H., Stevenson, D.S. \& Fitzpatrick, J.J., 1989. The effect of municipal waste-water irrigation and rate of $\mathrm{N}$ fertilization on petiole composition, yield and quality of Okanagan Riesling grapes. Can. J. Plant Sci. 69, 1285-1294.

Palazzo, A.J., 1981. Seasonal growth and accumulation of nitrogen, phosphorous, and potassium by orchardgrass irrigated with municipal wastewater. J. Environ. Qual. 10, 64-68.

Paranychianakis, N.V., Chartzoulakis, K.S. \& Angelakis, A.N., 2006. Influence of rootstock, irrigation level and recycled water on water relations and leaf gas exchange of Sultanina grapevines. Environ. Exp. Bot. 52, 185198.

Pederson, G.A., Brink, G.E. \& Fairbrother, T.E., 2002. Nutrient uptake in plant parts of sixteen forages fertilized with poultry litter: Nitrogen, phosphorous, potassium, copper, and zinc. Agron. J. 94, 895-904.

Prior, L.D., Grieve, A.M., Slavich, P.G. \& Cullis, B.R., 1992. Sodiumchloride and soil texture interactions in irrigated field-grown Sultana grapevines. 3. Soil and root-system effects. Aust. J. Agric. Res. 43, 10851100

Rusan, M.J.M., Hinnawi, S. \& Rousan, L., 2007. Long term effect of wastewater irrigation of forage crops on soil and plant quality parameters. Desalinisation 215, 143-152.

SAS, 1990. SAS/STAT users guide, version 8, first edition, volume 2. SAS Institute Inc., Campus Drive, Cary NC 27513.

SAWIS, 2013. South African wine industry statistics no. 37. Available at www.wosa.co.za/downloads/SAWIS Book 2013 eng.pdf (16 July 2013).

Shainberg, I. \& Oster, J.D., 1978. Quality of irrigation water. Pergamon Press, London.

Shapiro, S.S. \& Wilk, M.B., 1965. An analysis of variance test for normality (complete samples). Biometrika 52, 591-611.

Shepherd, H.L. \& Grismer, M.E., 1997. Constructed wetlands: An alternative for treating winery wastewater. Vineyard \& Winery Management, September/October, 65-68.

Stevens, R.M. \& Walker, R.R., 2002. Response of grapevines to irrigationinduced saline-sodic soil conditions. Aust. J. Exp. Agric. 42, 323-331.

Van Huyssteen, L. \& Van Zyl, J.L., 1984. Mulching in vineyards. Farming in South Africa, E.12.

Van Schoor, L., 2001. Environmental legislation in the viticultural and wine industry. Wineland, January, 114-117.

Vasquez-Montiel, O.N., Horan, J. \& Mara, D.D., 1996. Management of domestic wastewater for reuse in irrigation. Wat. Sci. Technol. 33, 355-362.

Wang, J., Wang G. \& Wanyan, H., 2007. Treated wastewater irrigation effect on soil, crop and environment: wastewater recycling in the loess area of China J. Environ. Sci. 19, 1093-1099. 